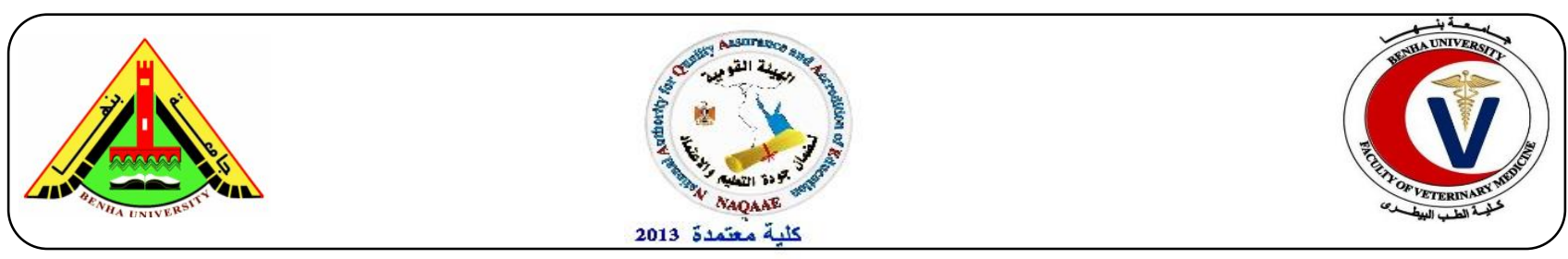

\title{
Bacteriological and molecular studies on some bacterial agents from neonatal calf diarrhea
}

\author{
${ }^{1}$ Ashraf A. Abd El-Tawab, ${ }^{1}$ Fatma I. Hofy, ${ }^{2}$ Sahar R. Mohamed, ${ }^{3}$ Reham, A. Salim \\ ${ }^{1}$ Bacteriology, Immunology and Mycology Dep., Fac. of Vet.Med., Benha Univ. \\ 2 Animal Health Research Institute, Doki, Giza. \\ ${ }^{3}$ Mashtoul -El souk veterinarian training center.
}

\section{A B S T R A C T}

Neonatal Calf diarrhea(NCD) is a commonly reported disease and considered as a major cause of economic loss to cattle producers. This study was done on 100 fecal swabs collected from diarrheic calves(0 day-2monthes) old during the period from December 2015 till January 2017 and subjected for bacteriological ,serological and molecular investigations. The infection rate of E.coli was $47 \%$ followed by Pseudomonas aeruginosa( $4 \%$ )and Salmonella Typhimurum( 1\%). Multi drug resistant appeared in the most tested microorganisms. Serogrouping of E. coli revealed the presence of $\mathrm{O}_{142}, \mathrm{O}_{55}, \mathrm{O}_{11}, \mathrm{O}_{27}, \quad \mathrm{O}_{157}, \mathrm{O}_{119}, \mathrm{O}_{26}$ and $\mathrm{O}_{127}$ by a percentage of $20.69 \%, 17.24 \%, 13.8 \%, 6.9 \%, 6.9 \% .6 .9 \%, 3.45 \%$ and 3.45\%, respectively. Multiplex PCR was applied for detection of virulence genes stx1(5/10),stx2(3/10) and eae(6/10)) which detected in E.coli and sth gene in Salmonella typhimurum and also (blaVIM(3/4), mexR(4/4)) genes for Pseudomonas aeruginosa were detected

Key words: Calf diarrhea, E.coli, Pseudomonas aeruginosa, Salmonella typhimurum, Virulence \&resistance genes.

(http://www.bvmj.bu.edu.eg)

(BVMJ-33(2): 465-475, 2017)

\section{INTRODUCTION}

Calves play an important role in the animal wealth either for herd replacement or as necessary source for good quality protein to fulfill the requirements of rapid increasing population (Zaki,2003).

The major enteric pathogens known to cause calf scour include bacteria such as Escherichia coli, Salmonella spp., Clostridium perfringens, Pseudomonas aeruginosa (Brown et al., 2007),
Antibiotic resistance is increasing among many bacterial species and is rapidly becoming a world health problem. The most important serogroups of E.coli causing disease in animals and human are $\mathrm{O}_{157}, \mathrm{O}_{26}$, $\mathrm{O}_{103}, \mathrm{O}_{111}, \mathrm{O}_{145}, \mathrm{O}_{45}, \mathrm{O}_{91}, \mathrm{O}_{113}, \mathrm{O}_{119}, \mathrm{O}_{121}$ and $\mathrm{O}_{128}$ which mostly belong to shiga toxin producing E.coli (STEC) pathotype (Jenkins et al., 2003 and Lin et al., 2011).

Multiplex PCR includes simultaneous amplification of more than one target gene 
including more than one set of primers in the same reaction mixture (Chandra et al., 2013).

It has been widely used in various studies for differentiation of $E$. coli pathotypes based on presence of genes encoding virulence factors (Müller et al., 2007) and serogrouping of E. coli based on presence of genes encoding serogroups (Fakih et al., 2016)

Salmonella induced diarrhea is a complex phenomenon involving several pathogenic mechanisms including production of enterotoxin. This enterotoxin production is mediated by the stn gene which is responsible for the maintenance of membrane composition and integrity( Lee et $\underline{a l ., 2009)}$

$P$. aeruginosa isolates including mex $\mathrm{R}$ and blaVIM genes showed considerable percent of resistance to carbabenem group and other classes of $\beta$-lactam. In addition, the values of biochemical and immunological parameters were affected (Awad et al., 2017) .So the current work aimed to study the bacteriological \& molecular characters of some aerobic bacteria in diarrheic neonatal calves.

\section{Materials and methods}

\subsection{Sample collection:}

A total number of 100 fecal swabs from diarrheic cattle and buffalo calves (30 samples from buffalo calves and 70 from cattle calves) of less than 2 months old at different seasons (winter and summer) during the period from December 2015 till January 2017 were examined bacteriologically.

The samples were collected, labeled and transported as soon as possible in ice box to the laboratory for bacteriological examination.

2.2 Bacteriological and biochemical examination:
Swabs were inoculated in Carry and Blair transport media and returned back to the laboratory for bacterial culturing and identification The collected samples were cultured onto sheep blood agar and Macconkey agar. The inoculated plates were incubated for 24-48 hours at $37^{\circ} \mathrm{C}$. The suspected colonies were picked up and tested for Gram's reaction. Colonies showed Gram negative bacilli were tested for catalase and coagulase. The positive colonies were tested by VITEK2 compact (Quinn et al.,2011)

\subsection{Antimicrobial sensitivity test:}

The isolates were subjected to the sensitivity test against different types of antibiotics, using the Vitek 2 system (Chatzigeorgiou et al., 2011)

\subsection{Serological identification}

Serological identification of E.coli is carried out according to Edwards and Ewing (1972) "table 3".

\subsection{Molecular examination:}

PCR amplification of different ribosomal DNA of virulent genes of both E.coli and salmonella and resistant genes of Pseudomonas aeruginosa were carried out using the following primers (table1)

\section{By using QIAamp® DNA Mini Kit} instructions (Catalogue no. M501DP100) (Sambrook et al, 1989). It was applied on 10 random isolated E.coli (stx1, stx2, eae) gene PCR ,and applied on one salmonella typhimurum isolate (stn)gene PCR also applied on four isolate of Pseudomonas aeruginosa (blaVIM-mexR)

\section{RESULTS}

\subsection{The results of bacteriological examination}

E.coli was isolated from 47 faecal samples with an infection rate of (47\%) followed by Pseudomonas aeruginosa 4(4\%) and Salmonella typhimurium 1 (1\%). 
3.2. The results of Antimicrobial sensitivity test:

The results of Antimicrobial sensitivity test showed distribution of multi drugs resistant bacteria in most tested strains (table2)

3.3. The results of serotyping of E.coli isolated from diarrheic calves

Serogrouping of $E$. coli isolates (29) revealed presence of $\mathrm{O}_{142}, \mathrm{O}_{55}, \mathrm{O}_{11}, \mathrm{O}_{27}, \mathrm{O}_{157}, \mathrm{O}_{119}, \mathrm{O}_{26}$ and $\mathrm{O}_{127}$ by a percentage of $20.69 \%, 17.24 \%, 13.8 \%, 6.9 \%, 6.9 \% .6 .9 \%, 3.45$ $\%$ and $3.45 \%$ respectively

\subsection{The results of molecular identification}

\subsubsection{Virulence genes}

\subsubsection{Virulence genes of E.coli}

Four samples were positive to stx 1 \& two samples were positive to stx 2 and one sample was positive to both stxl and stx2 and two samples were negative to both stxl\&stx2 (Figure $1 \& \quad 2$ ) of 10 random examined samples of E.coli meanwhile $\mathrm{O} 142, \mathrm{O} 26, \mathrm{O} 119, \mathrm{O} 55$ and $\mathrm{O} 157$ were positive to the intimin gene (eae) but $\mathrm{O} 27,0111 \& 0127$ were negative to eae (eae) of E.coli( Figure3)

3.4.1.2. The results of Salmonella typhinurum virulence genes using PCR

enterotoxin $(s t n)$ gene was detected in Salmonella typhinurum which is virulent gene responsible for pathogenicity (Figure4)

3.4.1.3.The results of Pseudomonas aeurignosa resistance genes identifications.

Four samples were positive to mexR and three samples were positive to bla VIM as showen in (Figure 5).

The distribution of both virulence and resistance genes were showed in table(4)

Table (1):primers used for the detection of virulent genes of E.coli and salmonella and resistant genes of pseudomonas aeruginosa F:Forward (3`-5`), R: Reverse(5`-3`)

get Primers sequences

Ie

F:ACACTGGATGATCTCAGTG G

R:CTGAATCCCCCTCCATTATG

F:CCATGACAACGGACAGCAGTT

R:ACACTGGATGATCTCAGTGG

F: ATG CTT AGT GCT GGT TTA GG

R: GCC TTC ATC ATT TCG CTT TC

IM F: TTTGGTCGCATATCGCAACG

R:CCATTCAGCCAGATCGGCAT

$: R$ F: GCGCCATGGCCCATATTCAG

R:ATT CGT AAC CCG CTC TCG TCC

F:TTG TGT CGC TAT CAC TGG CAA CC
Amplified

Segment Reference

(bp)

614

779

Dipineto et al., 2006

248

Bisi-Johnson et al., 2011

500

Amudhan et al., 2012

637

Sánchez et al., 2002

617

Murugkar et al., 2003 
Table (2): Distribution of multidrug resistant bacteria

\begin{tabular}{|c|c|c|c|c|c|c|}
\hline \multirow[t]{2}{*}{ Resistance patterns } & \multicolumn{2}{|c|}{ E. coli } & \multicolumn{2}{|c|}{$\begin{array}{l}\text { Pseudomonas } \\
\text { aeruginosa } \\
\mathrm{n}=4\end{array}$} & \multicolumn{2}{|c|}{$\begin{array}{l}\text { Salmonella } \\
\text { typhimurum } \\
\mathrm{n}=1\end{array}$} \\
\hline & No & $\%$ & No & $\%$ & No & $\%$ \\
\hline To one drug & 2 & 15.3 & - & - & - & - \\
\hline To only two drugs & - & - & - & - & - & - \\
\hline To only three drugs & 2 & 15.3 & 1 & 25 & - & - \\
\hline To more than three drugs & 6 & 46.15 & 3 & 75 & 1 & 100 \\
\hline To all drugs & - & & - & - & - & - \\
\hline
\end{tabular}

No.: Number of isolates. \%: Percentage in relation to No of tested isolates

$\mathrm{N}=$ number of samples

Table (3): Serotyping of E.coli isolated from diarrheic calves

\begin{tabular}{lll}
\hline E.coli serotypes & $\begin{array}{l}\text { Number } \\
\text { (out of 13) }\end{array}$ & \% of serotypes \\
\hline O142 & 6 & 20.69 \\
O55 & 5 & 17.24 \\
O111 & 4 & 13.8 \\
O27 & 2 & 6.9 \\
O157 & 2 & 6.9 \\
O119 & 2 & 6.9 \\
O127 & 1 & 3.45 \\
O26 & 1 & 3.45 \\
\hline
\end{tabular}

No.: Number of isolates. \%: Percentage in relation to No of tested isolated strain (E.coli (29)

Table (4) Distribution of virulence \&resistance genes from isolated microorganisms.

\begin{tabular}{|c|c|c|c|c|c|c|}
\hline \multirow{2}{*}{$\begin{array}{l}\text { The isolated } \\
\text { M.O } \\
\text { Gene }\end{array}$} & $\begin{array}{l}\text { E.coli } \\
\mathrm{n}=10\end{array}$ & & & \multirow{2}{*}{$\begin{array}{l}\text { Salmonella } \\
\text { typhimurum } \\
\mathrm{n}=1\end{array}$} & \multicolumn{2}{|c|}{$\begin{array}{l}\text { Pseudomonas } \\
\text { aeruginosa } \\
\mathrm{n}=4\end{array}$} \\
\hline & Stxl & Stx2 & eae & & Mex $\mathrm{R}$ & Bla VIM \\
\hline Positive samples & 5 & 3 & 6 & 1 & 4 & 3 \\
\hline
\end{tabular}




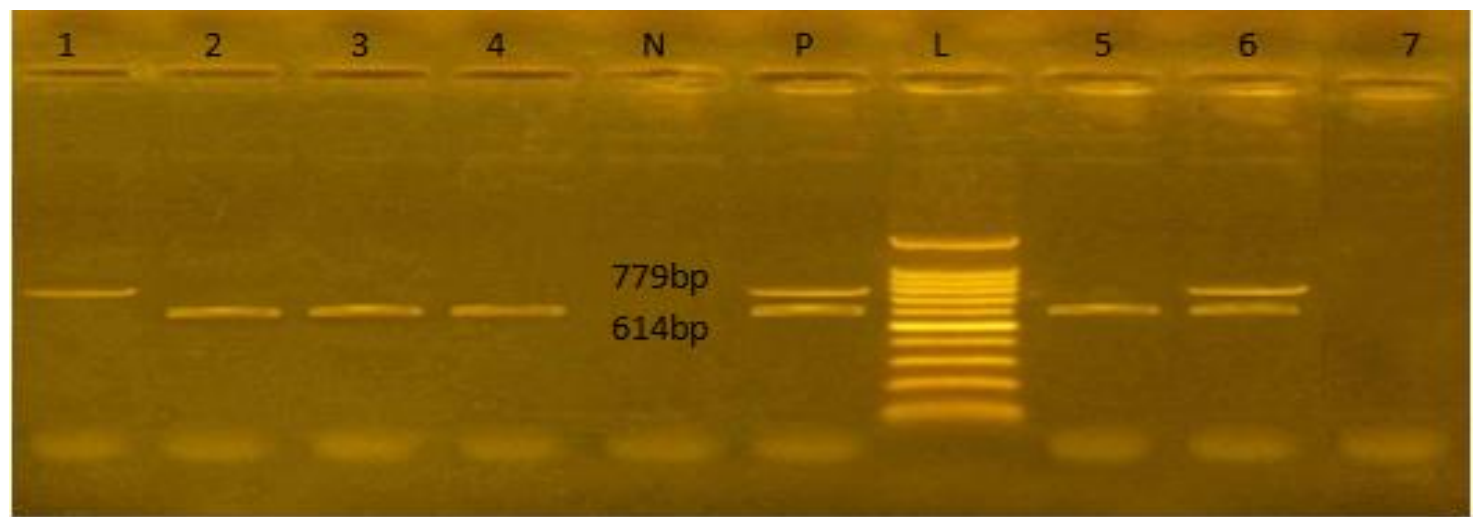

Fig(1): Agar gel electrophoresis showed results of multiplex PCR for detection of (stxl which amplified at $614 \mathrm{bp}$ and $s t x 2$ which amplified at $779 \mathrm{bp}$ ) genes from samples No(1-7) L: represent the molecular size marker(100pb plus ladder)

Lane 1 positive to stx2 (O119) Lane 2,3,4,5 positive to stxl(O127-

$$
\text { 0111-O124-O124) }
$$

Lane 6 positive to stx $1 \&$ stx $2(\mathrm{O} 157) \quad$-Lane 7 negative tostx $1 \&$ stx 2

$\mathrm{N}$ : control negative

P:control positive

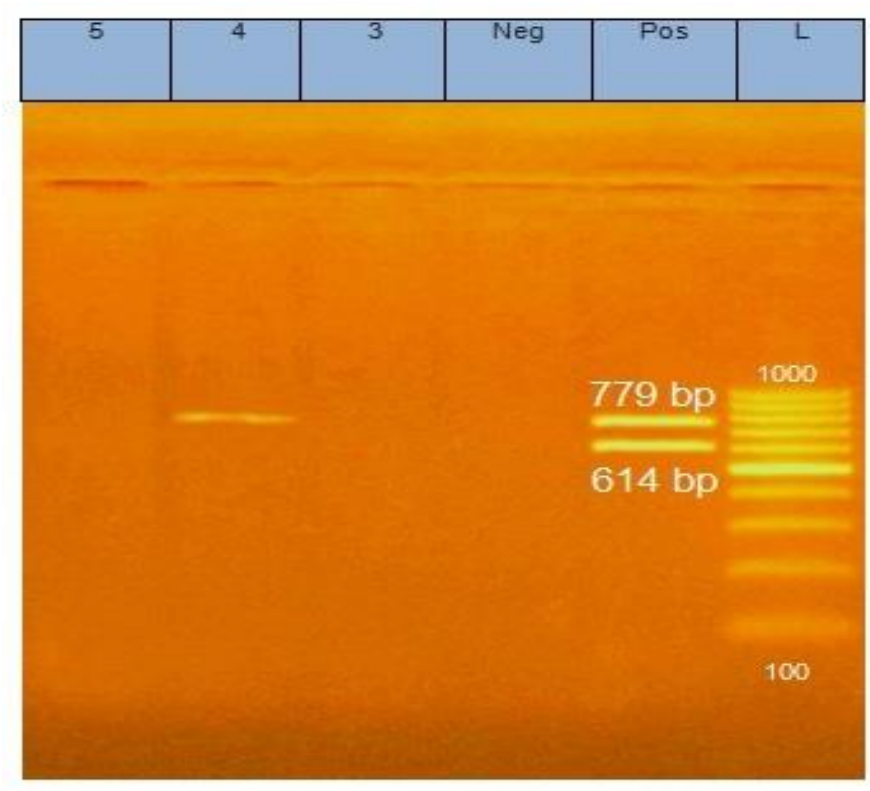

(Fig 2)Agar gel electrophoresis showed results of multiplex PCR for detection of stx1 and stx2 genes from E. coli samples No.(3 to 5)

L: represent the molecular size marker (100pb plus ladder) 3: negative for stx1 \& stx2 (O55)

4: positive of stx2 $779 \mathrm{bp}(\mathrm{O} 55) \quad$ 5- negative for stx $1 \&$ stx2 (O26) 


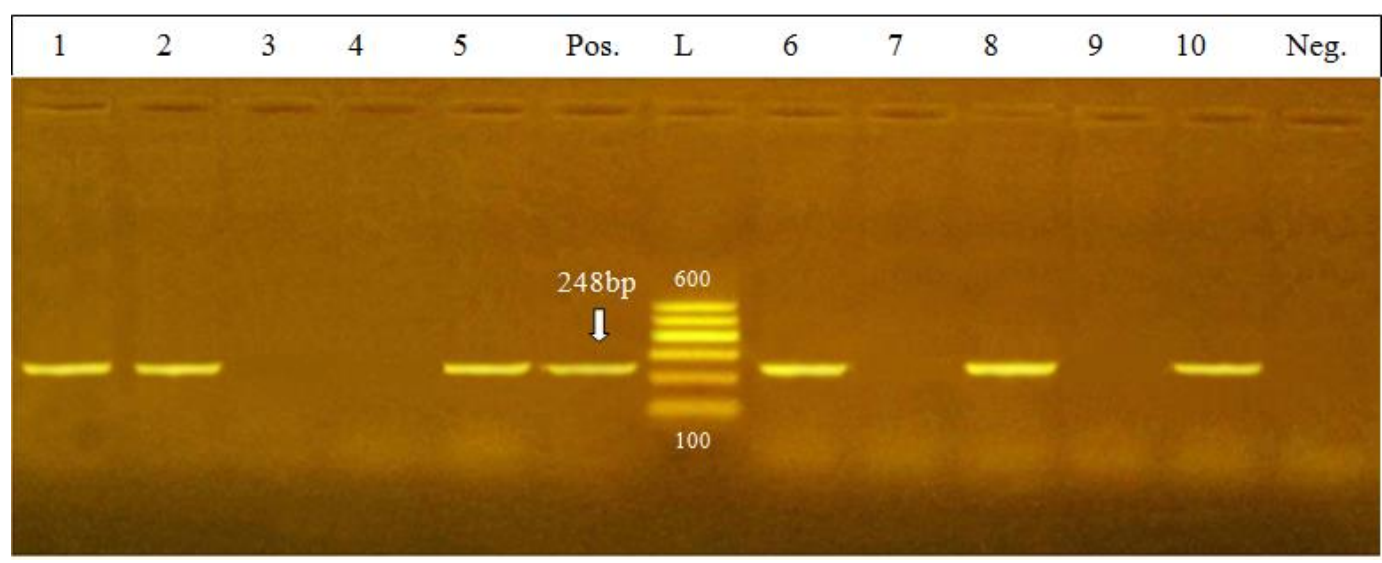

(fig3)Agarose gel electrophoresis showed results of uniplex PCR for detection of eae gene Neg : Negative control. Pos: Positive control of eae gene(248 bp)

$\mathrm{L}$ : represents the molecular size marker (100pb plus ladder)

(Lane1,2): Positive for o142 Lane 6 Positive for O119

(Lane 3.7) Negative for: O27\&O127 Lane 8: Positive for O55

(Lane 4) negative for,O111 Lane 9: Negative for O55

(Lane 5) Positive for,O26 L ane10, Positive for O157

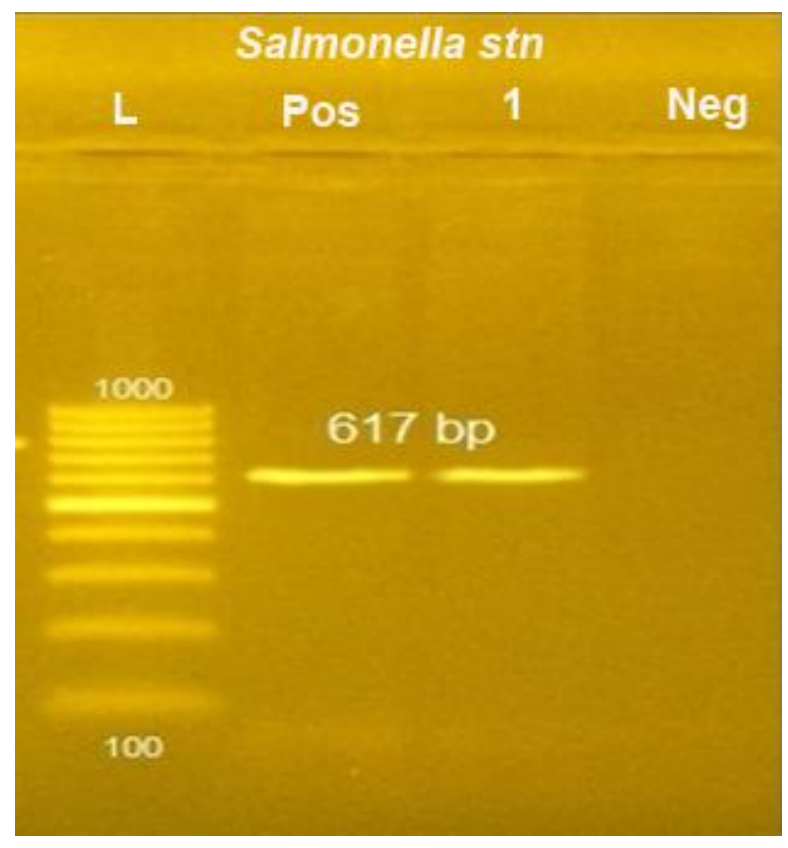

Figure(4)Agarose gel electrophoresis of uniplex PCR amplification Salmonella typhinurum of extracted DNA.

L: represents the molecular size marker (100-1000bp DNA ladder).

Neg.: Negative control

Pos.: Positive control of stn (617bp)

1 ; positive for stn gene (617bp) 
(a) $\operatorname{mexR}$

(b) BlaVIM

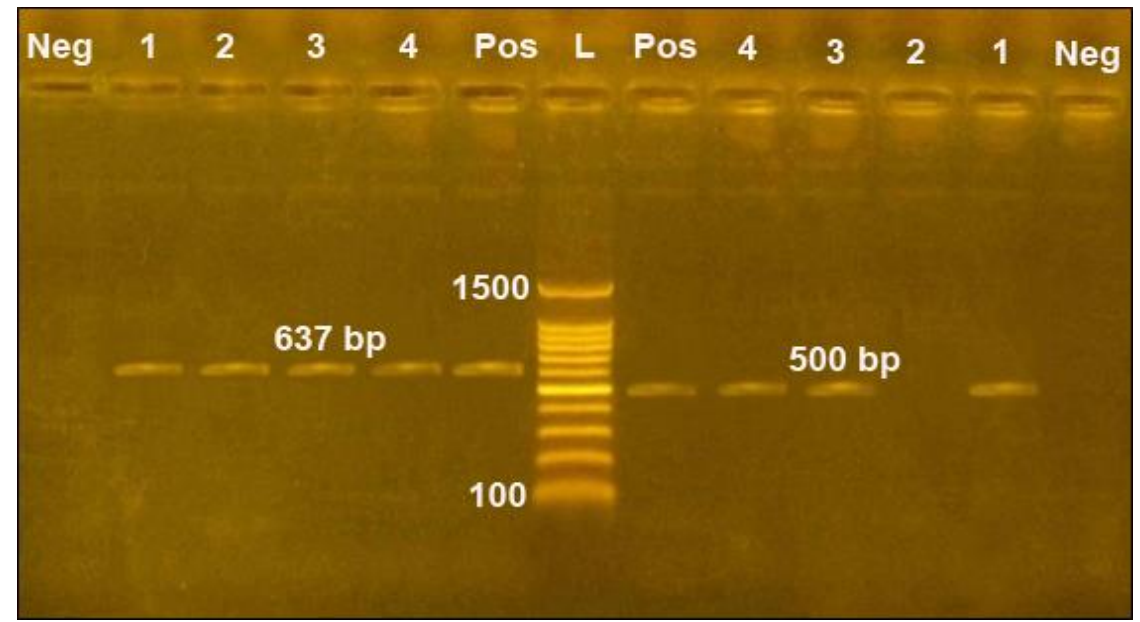

Figure (5 ): Agarose gel electrophoresis of multiplex PCR amplification of Ps. aeruginosa extracted DNA

(a): (mex R) gene. (b): (blaVIM) gene.

L: represents the molecular size marker (100-1500bp DNA ladder). Neg.: Negative control

Pos(b).: Positive control of blaVIM (500bp)

Pos(a).: Positive control of mexR (at 637bp)

Lane (a): 1a ,2a ,3a ,4a positive for mexR gene (637bp)

Lane (b): 1b, 3b , 4b positive for blaVIM gene(500bp)

Lane (2a) negative for blaVIM gene(500bp)

\section{DISCUSSION}

Neonatal calf diarrhea is considered as of the most important health problems in livestock causing high economic losses world wide either directly due to mortality and needs for treatment or indirectly through poor growth El-Seedy et al,(2016).

In the current study, E.coli was isolated with an infection rate of $47 \%$ as the main causative agent of family Enterobacteriaceae associated with diarrhea. This result was agreed with that described by Islam et al. (2015) who isolated E.coli with an incidence of $45.2 \%$.

The Pseudomonas aeruginosa which isolated from diarrheic calves in percentage of
$4 \%$. This result was similar to the result obtained by Ashraf( 2007) who isolated Pseudomonas aeruginosa from calves with diarrhea at apercentage of $4.9 \%$.

Although Salmonella spp is considered an important causative agent of NCD. In the present study it was isolated with low infection rate $(1 \%)$. The obtained result was nearly agreed with that recorded by Ok et al,(2009) and Asmaa,(2015) with an incidence of $1.2 \%$ and $0.8 \%$, respectively.

The Salmonella spp isolated from calves with diarrhea serotyped as Salmonella typhimurium. This result agreed with Nabih and Arafa,(2012). 
Serogrouping of 47 E.coli isolates using genes of 29 strains $O$ serogroups $\mathrm{O}_{142}, \mathrm{O}_{55}, \mathrm{O}_{111}, \mathrm{O}_{27}, \mathrm{O}_{157}, \mathrm{O}_{119}, \mathrm{O}_{127}$ and $\mathrm{O}_{26}$ revealed that $79.3 \%$ of E.coli strains were belonged to eight $\mathrm{O}$ serogroups and $20.7 \%$ were belonged to un identifiable serogroup (nontypable). From eight $\mathrm{O}$ serogroups identified, $\mathrm{O}_{142}$ was the most prevalent serogroup 20.7\%) followed by $\mathrm{O}_{55}$ and $\mathrm{O}_{111}$ at rate of $17.24 \%$ and $13.8 \%$ respectively ,then $\mathrm{O}_{27}, \mathrm{O}_{157}$ and $\mathrm{O}_{119}$ at a rate of $6.9 \%$ and the last two serogroups $\mathrm{O}_{127}$ and $\mathrm{O}_{26}$ were found at the same rate $3.45 \%$.

The above mentioned results agreed with results of Lin et al,(2011) who detected $\mathrm{O}_{157}, \mathrm{O}_{26}, \mathrm{O}_{142}$ and $\mathrm{O}_{111}$ and Aisha (2001) who isolated $\mathrm{O}_{26}, \mathrm{O}_{127}$ and $\mathrm{O}_{27}$.

Pseudomonas spp isolated from diarrheic calves were Pseudomonas aeruginosa, this result was in harmony to that recorded previously with Moustafa et al.( 2007) .

In the present study E.coli isolates were showed two of them resistant to at least one antimicrobial agent Table (2). Multidrug resistant was appeared on eight strains were similar to that obtained by Messaï et al.( 2013).

In the current work, Pseudomonas aeruginosa multi drug resistant to most antimicrobials agreed with previously work of Fekadu( 2010)and Ogunleye (2012).

Multidrug resistance present in the isolated sample of Salmonella typhimurum was agreed with results of Yhiler and Bassey( 2015).

Molecular characterization of E.coli isolated from diarrhea in neonatal calves through applying different conditions of uniplex and multiplex PCR for detection of genes encoding virulence factors(stx 1 ,stx2and eae).

E.coli strains carried different virulence genes, as the negative isolates of E.coli for tested virulence genes may be non pathogenic and the animals had diarrhea caused by other infectious agents or these isolates may carry other virulence genes not included in this study. The result is nearly similar to that obtained by Pourtaghi et $a l,(2013)$.

In this study, the rate of stx gene in isolated E.coli strains from cattle and buffalo calves was $30 \%$. Multiplex PCR assays approved the presence of intimin $(e a e)_{6 / 10}$ and Shiga toxins $\left(S T x 1_{5 / 10}\right.$ and $\left.S T x 2_{3 / 10}\right)$ in E.coli strains(10) $_{(10}$ which was agreed with Gharieb et al. (2015). In the current study E.coli $\mathrm{O}_{157}$ was positive to stxl, stx2 and eae genes, this agree with Karmali,( 2004).

Salmonella induced diarrhea is a complex phenomenon involving several pathogenic mechanisms including production of enterotoxins.

This enterotoxin production is mediated by the $s t n$ gene which is responsible for the maintenance of membrane composition and integrity (Chopra et al,1994).

The stn gene is present in Salmonella typhimurum(1/1) and this result is agreed with that observed by Moore and Feist,( 2007) and Lee et al. (2009).

The resistant genes for $P$. aeruginosa (MexR and blaVIM) were detected by PCR agreed with results of Zhao and $\mathrm{Hu},($ 2015)and Awad et al,(2017).

\section{CONCLUSION}

The main cause of diarrhea in the examined calves was E.coli and its virulence genes was stxl,stx 2 and eae which played an important role in its pathogenicity while, 
Salmonella which considered an important causative agent of NCD was recorded at low percentage with virulence gene ( $\operatorname{stn})$, On the other hand, Pseudomonas aeruginosa which is considered a real cause of diarrhea revealed presence of drug resistance genes (bla VIMmex $\mathrm{R}$ ) against beta-lactimase.

\section{REFERENCES}

Aisha R.A (2001): Comparative studies on diarrhea caused By E. coli in farm animals. J. Egypt. Vet. Med. Assoc., 61 (6): 39-49.

Amudhan M.S., Sekar U., Kamalanathan A. and Balaraman S. (2012): bla (IMP) and bla (VIM) mediated carbapenem resistance in Pseudomonas and Acinetobacter species in India. Journal of Infection in Developing Countries, 6: 757-762.

Ashraf N.M.R. (2007): Enzootic gram negative bacteria associated with diarrhea in neonates in Egypt. Ph. D. Thesis (Microbiology): Faculty of Veterinary Medicine, Alexandria University.

Asmaa M.B. (2015): Relationship between microorganisms and immunological parameters in calves with diarrhea .D.V.SC thesis microbiology and fungus. Faculty of Veterinary Medicine, Alexandria University.

Awad Ibrahim N., El-Metwally Farag V.M., Abd-El-Moaty A.M. and Magdy Atwa(2017): Resistant Gene of Pseudomonas aeruginosa in diseased Cattle; Biochemical and Immunological Parameters. World Vet. J., 7 (1): 5-13.

Bisi-Johnson, M.A.; Obi, C.L.; Vasaikar, S.D.; Baba, K.A. and Hattori, T. (2011): Molecular basis of virulence in clinical isolates of Escherichia coli and Salmonella species from a tertiary hospital in the Eastern Cape, South Africa. Gut Pathogens 2011, 3:9.

Brown, C.C.; Baker, D.C and Barker, I.K. (2007): Alimentary system. Jubb ,Kennedy and Palmer's pathology of domestic animals, $5^{\text {th }}$ Ed .Saunders Elsevier, St.Louis , MO,2:1-296.

Chandra,M.;Cheng,P.;Rondeau,G. ;Porwollik, S. and McClelland, M.(2013): Asingle step multiplex PCR for identification of six diarrheagenic E.coli pathotypes and Salmonella. International Journal of Medical Microbiology, 303(4):210-6.

Chatzigeorgiou, K.S., Sergentanis, T.N., Tsiodras, S., Hamodrakas, S.J., Bagos, P.G., (2011): Phoenix 100 versus Vitek 2 in the identification of gram-positive and gram-negative bacteria: a comprehensive meta-analysis. Journal of clinical microbiology,49; 3284-329.

Chopra AK, Peterson JW, Chary P, Prasad R.(1994): Molecular characterization of an enterotoxin from Salmonella Typhimurium. Microb Pathog; 16 : 8598.

Cruickshank R., Duguid J.P., Marmion B.P., and Swain R.H.A. (1975): Test for sensitivity to antimicrobial agents. Medical Microbiology. Longman Group Ltd., Great Britain, 190-208.

Dipineto, L.; Santaniello, A.; Fontanella, M.; Lagos, K.; Fioretti, A. and Menna, L.F. (2006). Presence of Shiga toxinproducing Escherichia coli O157:H7 in living layer hens. Letters in Applied Microbiology, 43: 293-295.

Edwards, P.R. and Ewing, W.H. (1972): Identification of Enterobacteriacae. Minneapolis,

El-Seedy, F.R.; Abed, A.H.; Yanni, H.A. and Abd El-Rahman, S.A.A. (2016): Prevalence of E. coli and Salmonella in 
neonatal calves with diarrhea. Journal of Basic and Applied Sciences Cell. Mol. Bio. 62, 21-28.

Fakih,I.;Thiry,D.;Duprez,J.N.;Saulmont,M.;Ig uchi,A.;Piérard,D.;Jouant,L.;Daube,G.; Ogura,Y.;Hayashi,T.;Taminiau, B. and Mainil,J.G.(2016): Identification of Shigatoxin-producing (STEC) and Enter pathogenic (EPEC) Escherichia coli in diarrheic calves and comparative genomics of bovine and human STEC. Veterinary Microbiology45: 112-120.

Fekadu, K. (2010): Pseudomonas infection in animals J. of Vet. Med. and Animal Health 2 (4): 55-58.

Gharieb R.M., Fawzi E.M., Attia N.E. and Bayoumi Y.H. (2015): calf diarrhea in Sharkia province, Egypt: diagnosis; prevalence, virulence profiles and zoonotic potential of the causative bacterial agents. International Journal of Agriculture Science and Veterinary Medicine, 3 (2): 71-87.

Islam A.K.M.A., Rahman M., Nahar A., Khair A. and Alam M.M. (2015): Isolation of pathogenic Escherichia coli from diarrheic calves in selective area of Bangladesh. Bangladesh Journal of Veterinary Medicine, 13 (1): 45-51.

\section{Jenkins,C.;Pearce,M.C.;Smith,A.W.;Knight,H} .I.;Shaw,D.J.;Cheasty,T.; Foster,G.; Gunn, G.J.; Dougan,G.; Smith, H.R. and Frankel, G.(2003): Detection of Escherichia coli serogroups $\mathrm{O}_{26}, \mathrm{O}_{103}$, $\mathrm{O}_{111}$ and $\mathrm{O}_{145}$ from bovine feces using immunomagnetic separation and PCR/DNA probetechniques. Letters in Applied Microbiology,37(3):207-1.

Karmali, M. A. 2004. Infection by Shiga toxin-producing Escherichia coli: an overview. Mol. Biotechnol. 26:117122.
Lee K., Iwata T., Shimizu M., Taniguchi T., Nakadia A., Hirota Y. and Hayashidani H. (2009): A novel multiplex PCR assay for Salmonella subspecies identification. J. Appl. Microbiol., 107: 805-811.

Lin, A.; Nguyen, L.; Lee, T.; Clotilde, L.M.; Kase, J.A.; Son, I.; Carter, J.M. and Lauzon, C.R. (2011): Rapid O serogrouping of the ten most clinically relevant STECs by Luminexmicrobeadbased suspension array. Journal of Microbiology Methods, 87(1):105-10.

MacFaddin, J.F. (2000): Biochemical tests for identification of medical bacterial,3rd ed., Lippincott, Williams \& Wilkins, Baltimore.

Messaï, R., Khelef, D., Boukhors, K., Radji, N., Goucem, R. and Hamdi, M. (2013): Antimicrobial susceptibility of Escherichia coli strains and drug resistance. African journal of microbiology research, vol. 7(21): 2668-2672.

Moore, M.M. and Feist, M.D. (2007): Realtime PCR method for Salmonella spp. targeting the stn gene. J. Appl. Microbiol. 102, 516-53.

Moustafa A.H., Hatab M.E and El Latif M.M. (2007): Study on bacterial causes of diarrhea in neonate calves in Dakahlia Province, Assiut. Vet. Med. J., 53: 114.

Müller , D.; Greune , L .; Heusipp ,G .; Karch , H .; Fruth , A.; Tschape , H. and Schmidt, M.A.(2007):Identification of unconventional intestinal pathogenic Escherichia coli isolates expressing intermediate virulence factor profiles by using a novel single step multiplex PCR. Applied and Environmental Microbiology,73(10):3380-90.

Murugkar, H.V.; Rahman, H. and \& Dutta, P.K. (2003): Distribution of virulence 
genes in Salmonella serovars isolated from man \& animals. Indian J. Med. Res., 117:66-70.

Nabih A.M. and Arafa M.M. (2012): Application of some lactobacilius strains product for control of salmonella typhimurium infection in diarrhoeic neonatal calves. Assiut Vet. Med. J., 58: 133.

Ogunleye, A. O. (2012):Identification of GyrA mutations conferring fluoroquinolone resistance in Pseudomonas aeruginosa isolated from poultry in Ibadan, Oyo State, Nigeria.African J. of Microbiol. Res., 6 (16):1249-1254.

Ok, M.; Güler, L.; Turgut, K.; Ok, Ü.; Sen, I.;Gündüz, I. K.; Birdane, M.F. and Güzelbektes, H. (2009): The studies on the causative agents of diarrhea in neonatal calves and determination of virulence gene markers of Escherichia coli strains by multiplex PCR. Zoonoses Public Health, 56(2):94-101.

Pincus, D.H. (2006) Microbial identification using the bioMerieux VITEK® 2System.Encyclopedia of Rapid Microbiological Methods. Bethesda, MD:Parenteral Drug Association.

Pourtaghi, H.; Dahpahlavan, V. and Momtaz, H. (2013): Virulence genes in Escherichia coli detected from diarrheic calfs in Iran. Comparative Clinical Pathology, 22(3):513-5.

Quinn, P.J.; Markey, B.K.; Leonard, F.C.; Hartigan, P.; Fanning, S. andFitzpatric, E.S. (2011): Veterinary microbiology and microbial diseases. $2^{\text {nd }}$ edition. Willy-Black well publisher. resistance in Pseudomonas aeruginosa isolated from poultry in Ibadan, Oyo State.
Sambrook, J.; Fritscgh, E.F.; and Mentiates (1989): Molecular coloning. A laboratory manual. Vol !., Cold spring Harbor Laboratotry press, New York.

Sanchez P., Linares J.F., Ruiz-Diez B., Campanario E., Navas A., Baquero F. and Martinez J.L. (2002): Fitness of in vitro selected Pseudomonas aeruginosa multidrug resistant mutants. The Journal of Antimicrobial Chemotherapy, 50: 657-664.

Vidal,M.;Kruger,E.;Durán,C.;Lagos,R.; Levine, M.; Prado,V.; Toro, C.and Vidal,R.(2005): Multiplex PCR assay to identify simultaneously the six categories of diarrheagenic Escherichia coli associated with enteric infections. Journal of Clinical Microbiology,43(10):5362-5.

Yhiler, N.Y. and Bassey, B.E. (2015): Critical segments in the dissemination and transmission of Salmonella in Calabar, Nigeria .Science Journal of Public Health.3(2): 168-174.

Zaki, E.R. (2003): Evaluation of effeminacies of some vaccine used for production of new born buffalo calves against E.coli $\mathrm{k}$ 99 by ELISA. J. Egypt Vet Med. Assoc., 63: 275-284.

Zhao W.H. and Hu Z.Q. (2015): Acquired metallo- $\beta$-lactamases and their genetic association with class 1 integrons and ISCR elements in Gram-negative bacteria. Future Microbiology, 10: 873887. 